\title{
The contribution of sulphuric acid to atmospheric particle formation and growth: a comparison between boundary layers in Northern and Central Europe
}

\author{
V. Fiedler ${ }^{1,2}$, M. Dal Maso ${ }^{2}$, M. Boy ${ }^{2}$, H. Aufmhoff ${ }^{1}$, J. Hoffmann ${ }^{1}$, T. Schuck ${ }^{1}$, W. Birmili ${ }^{3}$, M. Hanke ${ }^{1}$, J. Uecker ${ }^{1}$, \\ F. Arnold ${ }^{1}$, and M. Kulmala ${ }^{2}$ \\ ${ }^{1}$ Max-Planck Inst. for Nuclear Physics, (MPIK), Atmospheric Physics Div., P.O. Box 103980, 69029 Heidelberg, Germany \\ ${ }^{2}$ University of Helsinki, Dept. Physical Sciences, P. O. Box 64, FIN-00014 Univ. of Helsinki, Finland \\ ${ }^{3}$ Leibniz Institute for Tropospheric Research, Permoserstr. 15, D-04318 Leipzig, Germany
}

Received: 6 December 2004 - Published in Atmos. Chem. Phys. Discuss.: 3 February 2005

Revised: 6 June 2005 - Accepted: 16 June 2005 - Published: 20 July 2005

\begin{abstract}
Atmospheric gaseous sulphuric acid was measured and its influence on particle formation and growth was investigated building on aerosol data. The measurements were part of the EU-project QUEST and took place at two different measurement sites in Northern and Central Europe (Hyytiälä, Finland, March-April 2003 and Heidelberg, Germany, March-April 2004). From a comprehensive data set including sulphuric acid, particle number size distributions and meteorological data, particle growth rates, particle formation rates and source rates of condensable vapors were inferred. Growth rates were determined in two different ways, from particle size distributions as well as from a so-called timeshift analysis. Moreover, correlations between sulphuric acid and particle number concentration between 3 and $6 \mathrm{~nm}$ were examined and the influence of air masses of different origin was investigated. Measured maximum concentrations of sulphuric acid were in the range from $1 \times 10^{6}$ to $16 \times 10^{6} \mathrm{~cm}^{-3}$. The gaseous sulphuric acid lifetime with respect to condensation on aerosol particles ranged from 2 to $33 \mathrm{~min}$ in Hyytiälä and from 0.5 to $8 \mathrm{~min}$ in Heidelberg. Most calculated values (growth rates, formation rates, vapor source rates) were considerably higher in Central Europe (Heidelberg), due to the more polluted air and higher preexistent aerosol concentrations. Close correlations between $\mathrm{H}_{2} \mathrm{SO}_{4}$ and nucleation mode particles (size range: 3$6 \mathrm{~nm}$ ) were found on most days at both sites. The percentage contribution of sulphuric acid to particle growth was below $10 \%$ at both places and to initial growth below $20 \%$. An air mass analysis indicated that at Heidelberg new particles were formed predominantly in air advected from southwesterly directions.
\end{abstract}

Correspondence to: V. Fiedler

(verena.fiedler@mpi-hd.mpg.de)

\section{Introduction}

Aerosol particles are an important component of the Earth's atmosphere and influence human life in many different ways. In a global view they may have an impact on climate due to their major role in atmospheric chemistry and their ability to interact with the solar and terrestrial radiation fields (Ramanathan et al., 2001; Harshvardhan et al., 2002; Garrett et al., 2002).

Also humans can be directly affected, as aerosols may cause harm through inhalation (Stieb et al., 2002; Wichmann et al., 2000; Kim et al., 2000). In order to understand, predict and finally prevent those effects a detailed investigation of the sources and formation mechanisms of aerosol particles is needed.

In recent years sulphuric acid has been found to be a main player in atmospheric new particle formation and in subsequent particle growth (Boy et al., 2005; Kulmala, 2003; Kulmala et al., 2004a; Menon and Saxena, 1998; Weber et al., 1999; Birmili et al., 2003). Sulphuric acid can participate in binary, ternary and ion induced nucleation (Korhonen et al., 1999; Yue and Chan, 1979; Arnold, 1982). Therefore it is important to measure gaseous sulphuric acid and aerosol relevant parameters simultaneously in order to quantify the contribution of sulphuric acid to particle formation and growth.

The aim of the QUEST-project (Quantification of Aerosol Nucleation in the European Boundary Layer) was the qualitative and quantitative analysis of particle formation and growth in three different European regions. The first campaign (QUEST 1) took place in Mace Head (Ireland, coastal atlantic region) in spring 2002, the second (QUEST 2) in Hyytiälä (Finland, continental boreal forest area) in spring 2003 and the third in San Pietro Capofiume (Italy, QUEST 3a) and Heidelberg (Germany, QUEST 3b) in spring 2004.

(C) 2005 Author(s). This work is licensed under a Creative Commons License. 
Both San Pietro Capofiume and Heidelberg are highly polluted continental sites. These sites were selected in order to examine particle formation events in coastal regions, in clean continental air and in more anthropogenically influenced continental air.

During the campaign in Hyytiälä (17 March to 13 April 2003) and during the Heidelberg-campaign (27 February to the 4 April 2004) we have measured gaseous sulphuric acid concentrations and particle number size distributions continuously on 21 and 38 days, respectively. From these data particle growth rates, particle formation rates and source rates of condensable vapors were inferred and compared for both measurement sites.

\section{Materials and methods/experiment}

\subsection{Measurement sites}

\subsubsection{SMEAR II, Hyytiälä}

During QUEST 2 data were collected at the Station for Measuring Forest Ecosystem-Atmosphere Relations (SMEAR II) in Hyytiälä, Finland. The station is located in Southern Finland $\left(61^{\circ} 51^{\prime} \mathrm{N}, 24^{\circ} 17^{\prime} \mathrm{E}, 181 \mathrm{~m}\right.$ asl), with extended areas of Scots Pine (Pinus sylvestris) dominated forests. The conditions at the site are typical for a remote location. However, measurements were occasionally affected by pollution from the station buildings $(0.5 \mathrm{~km}$ away) and the city of Tampere (60 km away), both located in a west-south-west direction (215-265 $)$. In this work, measurements of gaseous $\mathrm{H}_{2} \mathrm{SO}_{4}$, temperature, solar radiation, humidity, wind-direction, particle number concentration and size distribution (3-500 nm) have been evaluated. A more detailed description of SMEAR II and its instrumentation is available in Kulmala et al. (2001) and http://www.honeybee.helsinki.fi/smear/.

\subsubsection{Heidelberg}

Data were collected at the MPI-K Heidelberg (Max Planck Institute for Nuclear Physics, http://www.mpi-hd.mpg.de), Germany $\left(49^{\circ} 23^{\prime} \mathrm{N}, 08^{\circ} 41^{\prime} \mathrm{E}, 350 \mathrm{~m}\right.$ a.s.l.) about $4 \mathrm{~km}$ eastwards of Heidelberg on a hill $200 \mathrm{~m}$ above the city within deciduous forest area (beech, maple, chestnut, birch, oak). A farmhouse and a rehabilitation centre are located at a distance of about $0.5 \mathrm{~km}$. To the east of the measurement site, Heidelberg is surrounded by forested hills (Odenwald) with a maximum altitude of $626 \mathrm{~m}$ a.s.l. To the west, Heidelberg borders on the Rhine valley where several large cities with various industrial complexes and power stations are settled (population of around 7 million within a radius of $80 \mathrm{~km}$ ). This region is considered to be one of the most polluted areas in Germany. During QUEST 3b measurements of $\mathrm{H}_{2} \mathrm{SO}_{4}$, solar radiation, temperature, humidity, wind direction/speed and particle number size distributions were carried out. Particle number size distributions (size range 3-900 nm) were measured using a flow-regulated twin Differential Mobility Particle Sizer (DMPS) (see, e.g., Birmili et al., 1999). Ambient aerosol was conducted from outdoors into the DMPS system, and classified in a sheath air stream at $R H<5 \%$. The additional meteorological data were measured using a standard weather station (WM 918 by Huger Electronics) with wind measurements on the roof of one of the MPI-K buildings.

\subsection{Measurements of gaseous sulphuric acid}

Gaseous sulphuric acid was measured at both sites by a chemical ionization mass spectrometer (CIMS) built by the MPI-K Heidelberg (Reiner and Arnold, 1993, 1994; Hanke et al., 2002). The principle of this measurement method is to convert the hardly detectable trace gas into more easily detectable product ions through a highly efficient ion-molecule reaction (IMR). The main components of this CIMS apparatus used in QUEST 2 and 3 are an ion trap mass spectrometer, a flow reactor, the ion source and a $\mathrm{H}_{2} \mathrm{SO}_{4}$-source used for calibration. In the ion source reagent ions of the type $\mathrm{NO}_{3}^{-}\left(\mathrm{HNO}_{3}\right)_{n}$ are produced and subsequently introduced into the flow reactor. The atmospheric air (ambient atmospheric pressure), that should be analyzed, is passed through the flow reactor. There the ions undergo an IMR of the type $\mathrm{NO}_{3}^{-}\left(\mathrm{HNO}_{3}\right)_{n}+\mathrm{H}_{2} \mathrm{SO}_{4} \rightarrow \mathrm{HSO}_{4}^{-}\left(\mathrm{HNO}_{3}\right)_{m}+(n-m) \mathrm{HNO}_{3}$ with the trace gas. The rate coefficients of these reactions are close to the ion-molecule collision rate coefficients (around $2 \times 10^{-9} \mathrm{~cm}^{3} \mathrm{~s}^{-1}$ ). Using the mass spectrometer the abundance ratio of product and reagent ions is measured. From this ion abundance ratio the $\mathrm{H}_{2} \mathrm{SO}_{4}$-concentration in the flow reactor can be determined, which is typically about $50 \%$ of the ambient atmospheric sulphuric acid concentration due to $\mathrm{H}_{2} \mathrm{SO}_{4}$-losses to the walls of the sampling line and the flow reactor. In order to quantify these losses the $\mathrm{H}_{2} \mathrm{SO}_{4}$-source is used for calibrations (production of $\mathrm{OH}$-radicals that lead in reaction with $\mathrm{SO}_{2}$ to a certain amount of $\mathrm{H}_{2} \mathrm{SO}_{4}$ ). Moreover, the $\mathrm{H}_{2} \mathrm{SO}_{4}$-background signal of the CIMS-instrument is determined. This affects the $\mathrm{H}_{2} \mathrm{SO}_{4}$-detection limit.

During QUEST 2 and $3 \mathrm{~b}$ this detection limit was as low as about $1 \times 10^{5}$ molecules $\mathrm{cm}^{-3}$ corresponding to an atmospheric mole fraction of $4 \times 10^{-15}$ or $4 \mathrm{ppq}$. The timeresolution of the $\mathrm{H}_{2} \mathrm{SO}_{4}$-measurements was better than $10 \mathrm{~s}$ but usually $\mathrm{H}_{2} \mathrm{SO}_{4}$-concentrations were integrated over $100 \mathrm{~s}$ to reduce the statistical error. The absolute uncertainty of the measured $\mathrm{H}_{2} \mathrm{SO}_{4}$-concentration is plus or minus $30 \%$, mainly due to uncertainties of the calibration setup (uncertainties of the $\mathrm{OH}$-production, $\mathrm{OH}$ losses prior to reaction with $\mathrm{SO}_{2}$ etc.). A paper addressing in more detail the CIMS apparatus is in preparation (Aufmhoff et al., in preparation, $\left.2005^{1}\right)$.

\footnotetext{
${ }^{1}$ Aufmhoff, H., Fiedler, V., Hanke, M. and Arnold, F.: Atmospheric measurements of gaseous sulphuric acid: Deployment of an Ion Trap CIMS-instrument, in preparation, 2005.
} 


\subsection{Theory}

\subsubsection{Condensation sink}

The aerosol condensation sink (CS) determines how rapidly molecules will condense onto pre-existing aerosols (Kulmala et al., 2001) and can be calculated from

$\mathrm{CS}=4 \pi D \int_{0}^{\infty} r \beta_{M}(r) n(r) d r=4 \pi D \sum_{i} \beta_{M} r_{i} N_{i}$

with $D$ being the diffusion coefficient of sulphuric acid, $\beta_{M}$ the transitional correction factor typically calculated using the expression by Fuchs and Sutugin (1971), $N_{i}$ and $r_{i}$ are the number concentration and the radius of the particles in the i'th size class measured with a DMPS system at dry relative humidity. In our case the condensation sink values were calculated over the measured size range at both stations, so from 3 to $500 \mathrm{~nm}$ in Hyytiälä and from 3 to $900 \mathrm{~nm}$ in Heidelberg. The different upper limits of the measured size ranges do not affect a comparison of the CS at the two stations very much, as the concentration of particles above $500 \mathrm{~nm}$ was always quite low in Heidelberg (usually below $200 \mathrm{~cm}^{-3}$, see Fig. 3).

\subsubsection{Growth rates}

Growth rates were calculated in two different ways. The first method was to obtain a growth rate for the entire particle formation event by tracking the temporal evolution of the nucleation mode from initial sizes of $3 \mathrm{~nm}$ up to $25 \mathrm{~nm}$. The point in time of the highest concentration was determined for each size class separately by fitting a lognormal distribution to the temporal evolution of the particle number size distribution of that size class. From these values a growth rate GR1 in $\mathrm{nm} \mathrm{h}^{-1}$ was calculated (see e.g. Mäkelä et al., 2000).

Secondly, we used a so-called timeshift analysis, which compared the shape of two curves - sulphuric acid and the particle number concentration between 3 and $6 \mathrm{~nm}(\mathrm{~N} 3$ hereafter). A similar analysis has been used by Weber et al. (1997) and Harrison et al. (2000). In Fig. 1 the number concentration of the smallest detectable particles N3 and the sulphuric acid concentration are plotted versus time for one example day in Hyytiälä. The shape of the N3 curve usually follows the sulphuric acid curve with a certain time lag. The time lag is thought to be the result of a $\mathrm{H}_{2} \mathrm{SO}_{4}$-driven formation of $1 \mathrm{~nm}$ particles (widely used assumption for the approximate critical cluster size) and the detection of $3 \mathrm{~nm}$ particles in the DMPS. Hence the time lag reflects the time required for condensational and coagulational growth. Consequently, this time lag allows to estimate a growth rate for the initial particle growth from $1 \mathrm{~nm}$ to $3 \mathrm{~nm}$ (GR2 hereafter).

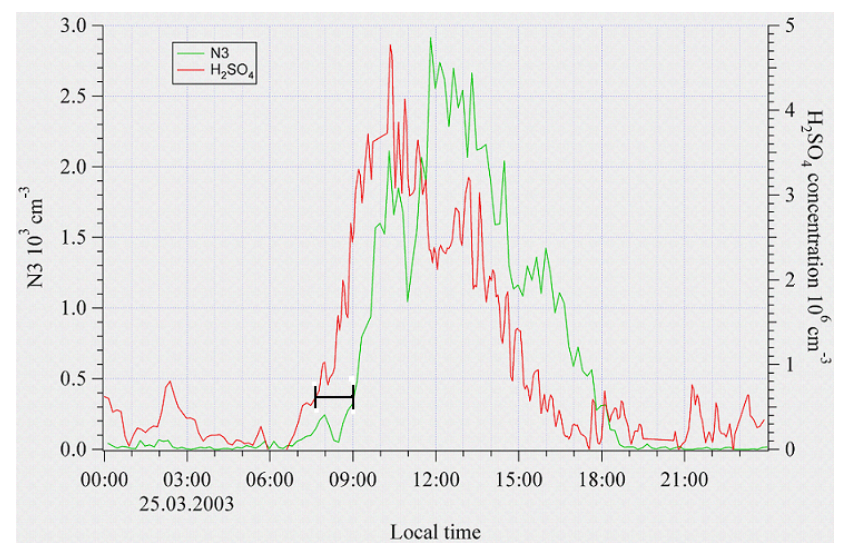

Fig. 1. Sulphuric acid concentration $\left(\mathrm{H}_{2} \mathrm{SO}_{4}\right)$ and particle concentration between 3 and $6 \mathrm{~nm}(\mathrm{~N} 3)$ versus time for one example day in Hyytiälä. The graph shows the similarity of the shape of the two curves. The time lag, marked by a black bar, indicates the time required for the initial growth from $1 \mathrm{~nm}$ to $3 \mathrm{~nm}$. This time interval was chosen for the calculations of growth rate 2 , a growth rate for the initial growth.

\subsubsection{Particle formation rates}

The particle formation rate $\mathrm{J} 3$ was determined from the total concentration of particles with diameters smaller than $25 \mathrm{~nm}$ $\left(N_{3-25}\right)$.

$\frac{d N_{3-25}}{d t}=J 3-\operatorname{CoagSc} \cdot N_{3-25}-G R_{\text {out }} \cdot N_{3-25}$

with $\operatorname{CoagSc}$ being the coagulational scavenging coefficient and $G R_{\text {out }}$ a coefficient that accounts for growth out of the $25 \mathrm{~nm}$ range. Coagulational scavenging causes about $30 \%$ loss of fresh particles while growth to diameters bigger than $25 \mathrm{~nm}$ can be neglected (Kerminen et al., 2001). Therefore a lower limit for the formation rate $\Delta$ concentration $/ \Delta t$ in $\mathrm{cm}^{-3} \mathrm{~s}^{-1}$ was calculated for a time interval between the times when the particle concentration started to increase and when it ceased to increase near its maximum value (Kulmala et al., 2004b). This calculation builds on the assumption that particles are formed in-situ in the air mass under observation and is, particularly, not valid when a different air parcel is transported to the measurement site vertically or horizontally.

\subsubsection{Condensable vapor concentration and source rates}

The condensable vapor concentration $C_{v a p}$ is a property for the expected amount of vapor that is necessary to initiate particle formation and to maintain a certain growth rate.

If the growth rate of the particles is known and with the assumption of binary nucleation of sulphuric acid and water, $C_{v a p}$ can be integrated following Kulmala (1988). Notably, $C_{v a p}$ is a linear function of the particle growth rate in the size range of newly formed nano-particles: 
$C_{\text {vap }}=1.37 \times 10^{7} \mathrm{~cm}^{-3} \times G R$ where GR is given in $\mathrm{nm} \mathrm{h}^{-1}$. The factor $1.37 \times 10^{7}$ is mainly dependent on the product of mass and diffusion coefficient of the condensing vapor. In principle one can say, the lower the mass, the higher the diffusion coefficient, so their product remains rather constant (Kulmala et al., 2001). Using this we can estimate a source rate $Q$ of the vapor. According to Kulmala (2001) we get for the condensable vapor concentration

$$
\frac{d C}{d t}=Q-\mathrm{CS} \cdot C
$$

with $C=C_{\text {vap }}-C_{\text {saturation }}$. Kulmala et al. (1998) showed, that $C_{\text {saturation }} \approx 3 \cdot 10^{6}$, which is more than one order of magnitude smaller than $C_{\text {vap }}$, which means that $C_{\text {saturation }}$ can be neglected.

Now if we assume steady state

$\frac{d C_{v a p}}{d t}=0$

we get

$$
Q=\mathrm{CS} \cdot C_{\text {vap }}
$$

as a value for the source rate of the condensable vapor.

\section{Measured data}

A total number of 19 particle formation events in Hyytiälä and 10 in Heidelberg were observed, of which 8 in Hyytiälä (3 in Heidelberg) were classified class 1, 6 (3) class 2 and 5 (4) class 3. The classification uses the following criteria: class 1 means a clear formation of new $3 \mathrm{~nm}$ particles and their following extended growth, class 2 means clear formation but the growth is less pronounced and class 3 means that there is some formation but no or only very poor growth is visible (Mäkelä et al., 2000 and Boy and Kulmala, 2002).

The concentration of preexistent background aerosol (mainly particles between 10 and $300 \mathrm{~nm}$ ) was always slightly higher in Heidelberg than in Hyytiälä, but at both sites new particle formation was preceded by a strong decline of the background particle concentration on most event days. In those cases the total particle number concentration was below $7000 \mathrm{~cm}^{-3}$ in Hyytiälä and below $10000 \mathrm{~cm}^{-3}$ in Heidelberg whereas it reached usually around $15000 \mathrm{~cm}^{-3}$ at both places during daytime.

Since the Heidelberg measurement site was located on the western slope of a hilly area, number size distributions usually indicated that relatively clean air prevailed during nighttimes, whereas more polluted air arrived from the Rhine valley in the morning when the boundary layer developed, and enveloped the measurement site. Yet this feature did not exist on 7 of the 10 event days and was less pronounced on the other 3 event days.

In Figs. 2 and 3 some DMPS plots are shown as examples for class 1 , class 2 and class 3 events at both places. A particle formation event in the early morning or late evening, that occurred sometimes in Heidelberg (see first panel in figure 3) was definitely not caused by sulphuric acid, as the $\mathrm{H}_{2} \mathrm{SO}_{4}$ concentration was very low at those times.

Figures 4 and 5 show the measured sulphuric acid concentrations and the condensation sink in Hyytiälä and Heidelberg, respectively. The concentrations of sulphuric acid were in the same range $\left(1 \times 10^{6}-16 \times 10^{6} \mathrm{~cm}^{-3}\right)$, but the mean was slightly higher in Heidelberg $\left(3.46 \times 10^{6} \mathrm{~cm}^{-3}\right)$ compared to Hyytiälä $\left(3.04 \times 10^{6} \mathrm{~cm}^{-3}\right)$. The values of the condensation sink ranged from 0.002 to $0.035 \mathrm{~s}^{-1}$ in Heidelberg and from 0.0005 to $0.007 \mathrm{~s}^{-1}$ in Hyytiälä. The corresponding lifetime $\mathrm{CS}^{-1}$ is consequently 2 to $33 \mathrm{~min}$ in Hyytiälä and 0.5 to $8 \mathrm{~min}$ in Heidelberg. Moreover, the variation was much higher in Heidelberg, especially during daytime. These high CS values are indicative of the higher degree of pollution (primary particle emissions, secondary aerosol formation) in Central Europe. Furthermore the variations in Heidelberg reflect the influence of nearby anthropogenic sources, particularly localized industry, traffic and households.

In Figs. 6 and 7 solar radiation and temperature during both campaigns are shown. In Hyytiälä specifically UV-B radiation (wavelength $\lambda<320 \mathrm{~nm}$ ) was measured by use of a UV-B sensor; in Heidelberg a Lux sensor (ELV, MultimeterInterface) was used, with a sensitivity maximum between 500 and $600 \mathrm{~nm}$ wavelength. This accounts for the divergence of absolute radiation values (up to 40 times higher) in Heidelberg. UV-B radiation with wavelengths smaller than $310 \mathrm{~nm}$ is responsible for the formation of $\mathrm{O}\left({ }^{1} \mathrm{D}\right)$ via the photolysis of ozone, so this is the most interesting wavelength section with regard to sulphuric acid formation. Nevertheless, the diurnal variation of the UV-B radiation follows the visible light, with exception of early morning and late evening, when due to the longer way through the atmosphere especially short wavelengths are filtered out of the solar spectrum. These data were not used for calculations in this paper, but will be of interest for future model calculations on nucleation.

During QUEST 2, 16 of the 19 event days were completely sunny whereas the days during QUEST 3b were often cloudy or rainy especially in the beginning of March. On those days very low values of sulphuric acid were measured. Five of the ten event days in Heidelberg were sunny. The mean temperature was about $10^{\circ} \mathrm{C}$ in Heidelberg and about $2^{\circ} \mathrm{C}$ in Hyytiälä.

\section{Results and discussion}

Table 1 gives an overview of measured and inferred data on event days derived directly from DMPS plots. Table 2 gives the same inferred data taking GR2 as input values. Overall the mean values for all calculated quantities were higher in Heidelberg compared to Hyytiälä. For most values like CS and $\mathrm{H}_{2} \mathrm{SO}_{4}$ we would expect this due to the more polluted air in Heidelberg. 

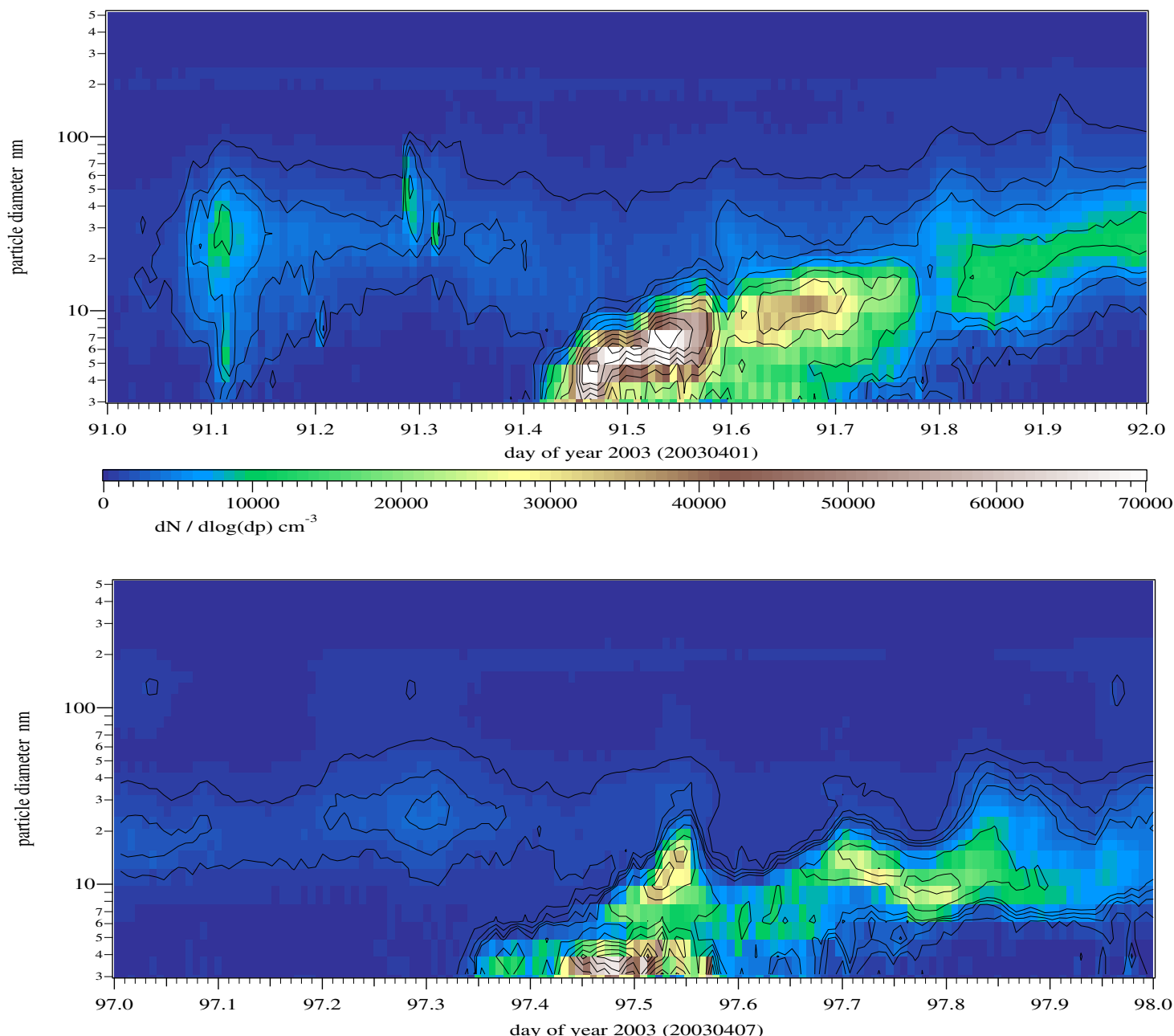

\begin{tabular}{cccccc|c|c|c|}
0 & 10000 & 20000 & 30000 & 40000 & 50000 & 60000 & 70000
\end{tabular}

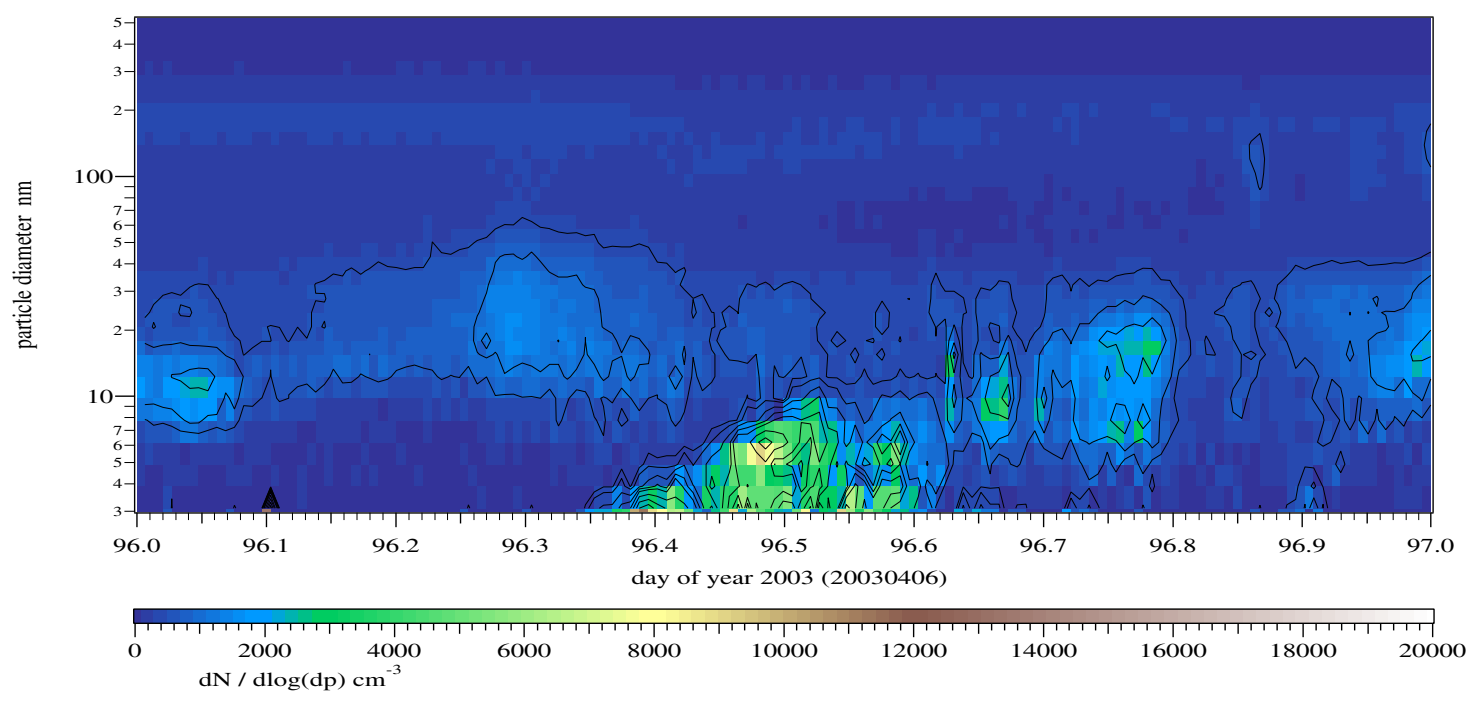

Fig. 2. Hyytiälä: Examples for class 1, class 2 and class 3 events as DMPS plots. Particle diameter is plotted versus time, particle number concentration as color code. During new particle formation the particle concentration reached a maximum of $70000 \mathrm{~cm}^{-3}$ for class 1 and class 2 events, a maximum of $20000 \mathrm{~cm}^{-3}$ for class 3 . The background particle concentration was usually below $7000 \mathrm{~cm}^{-3}$. 

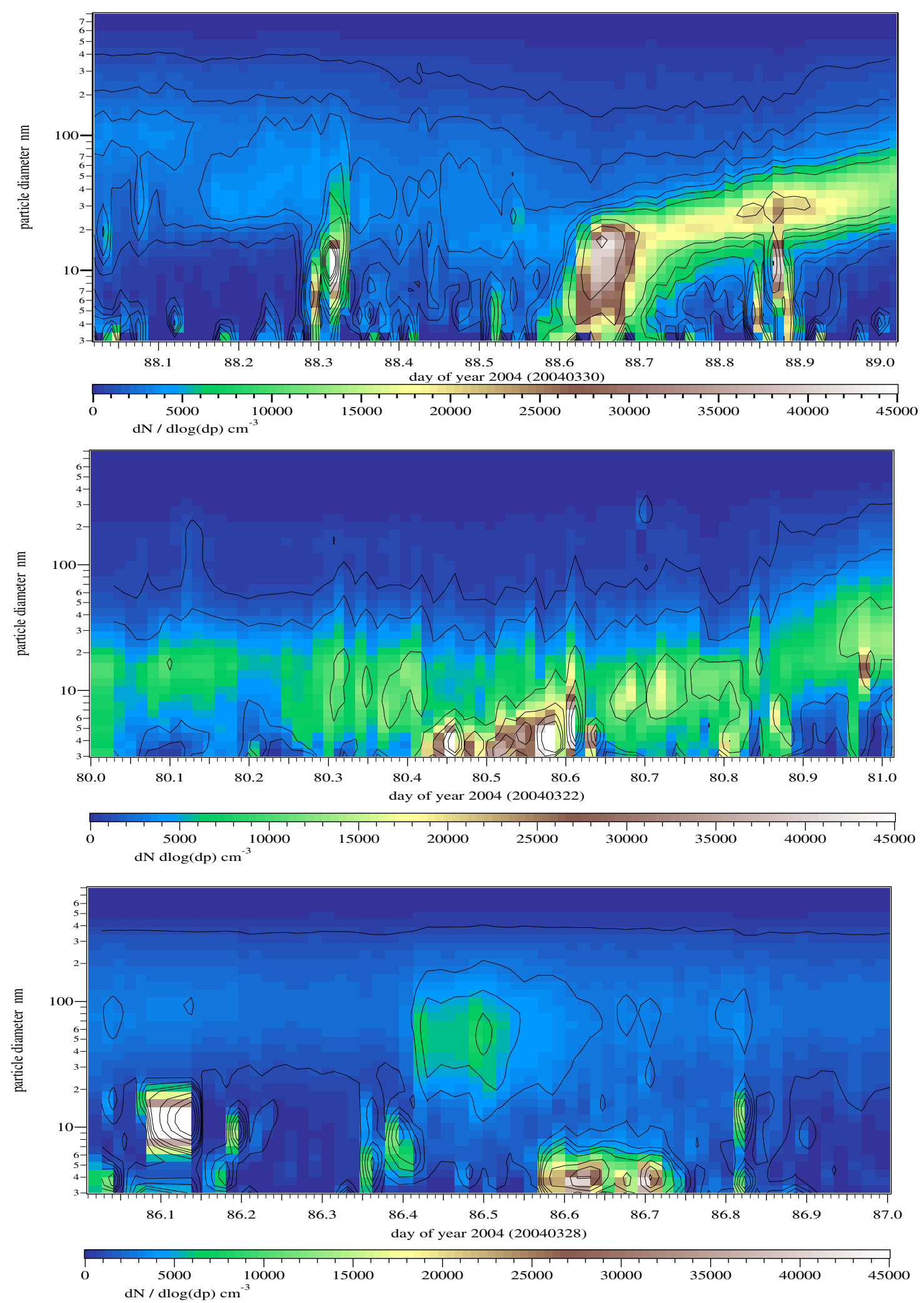

Fig. 3. Heidelberg: Examples for class 1, 2 and class 3 events. During new particle formation the particle concentration reached a maximum of $45000 \mathrm{~cm}^{-3}$. The background concentration was usually below $10000 \mathrm{~cm}^{-3}$. In the third panel the high concentrations around $86.1 \mathrm{were}$ not real but caused by an instrument error. 
Table 1. For Hyytiälä and Heidelberg, respectively: Growth Rate 1 (GR1) for the growth starting at 3 nm, formation rate (J3), condensable vapor concentration (Cvap), mean sulphuric acid concentration during event $\left(\mathrm{H}_{2} \mathrm{SO}_{4}\right)$, mean condensation sink (CS mean), source rate (Q), percentage of $\mathrm{H}_{2} \mathrm{SO}_{4}$ of the condensable vapor. All calculations basing on GR1. The correlation coefficient $\mathrm{r}$ from the correlation analysis for $\mathrm{H}_{2} \mathrm{SO}_{4}$ and $\mathrm{N} 3$ and the air mass direction are also added.

\begin{tabular}{|c|c|c|c|c|c|c|c|c|c|c|c|}
\hline Date & Starting time & class & GR 1 & $\mathrm{~J} 3$ & Cvap & $\mathrm{H}_{2} \mathrm{SO}_{4}$ & CS mean & Q & Perc. $\mathrm{H}_{2} \mathrm{SO}_{4}$ & $\mathrm{r}$ & Direction \\
\hline & & & $\left(\mathrm{nm} \mathrm{h}^{-1}\right)$ & $\left(\mathrm{cm}^{-3} \mathrm{~s}^{-1}\right)$ & $\left(\mathrm{e} 8 \mathrm{~cm}^{-3}\right)$ & $\left(\mathrm{e} 6 \mathrm{~cm}^{-3}\right)$ & $\left(\mathrm{e}-3 \mathrm{~s}^{-1}\right)$ & $\left(\mathrm{e} 5 \mathrm{~cm}^{-3} \mathrm{~s}^{-1}\right)$ & $\%$ & & \\
\hline \multicolumn{12}{|l|}{ Hyytiälä } \\
\hline 18 March 2003 & $12: 00$ & 2 & 1,60 & 0.27 & 0.22 & 2.10 & 1.00 & 0.22 & 9.50 & 0.56 & \\
\hline 19 March 2003 & $12: 00$ & 3 & 3.00 & 0.23 & 0.41 & 0.60 & 0.90 & 0.37 & 1.50 & 0.44 & $\mathrm{~N} / \mathrm{NW}$ \\
\hline 20 March 2003 & 10:00 & 1 & 1.70 & 0.46 & 0.23 & 2.20 & 0.80 & 0.18 & 9.60 & 0.69 & $\mathrm{~N} / \mathrm{NW}$ \\
\hline 21 March 2003 & $10: 00$ & 1 & 3.10 & 1.11 & 0.42 & 3.70 & 1.90 & 0.80 & 8.80 & 0.61 & W/SW \\
\hline 25 March 2003 & 10:00 & 1 & 2.60 & 0.49 & 0.36 & 2.60 & 1.10 & 0.40 & 7.20 & 0.77 & $\mathrm{~N} / \mathrm{NW}$ \\
\hline 26 March 2003 & 10:00 & 2 & 3.90 & 1.00 & 0.53 & 4.40 & 2.90 & 1.54 & 8.30 & 0.82 & W/SW \\
\hline 27 March 2003 & $13: 30$ & 3 & 3.00 & 0.10 & 0.41 & 3.40 & 4.10 & 1.68 & 8.30 & 0.59 & W/SW \\
\hline 28 March 2003 & $10: 00$ & 1 & 3.30 & 0.45 & 0.45 & 1.80 & 1.70 & 0.77 & 4.00 & 0.54 & \\
\hline 29 March 2003 & $10: 30$ & 2 & 6.00 & 1.72 & 0.82 & 2.30 & 2.30 & 1.89 & 2.80 & 0.69 & $\mathrm{~W} / \mathrm{SW}$ \\
\hline 31 March 2003 & 13:00 & 3 & 4.10 & 1.01 & 0.56 & 2.60 & 1.00 & 0.56 & 4.60 & 0.24 & N/NW \\
\hline 6 April 2003 & 09:00 & 3 & 1.80 & 0.14 & 0.25 & 1.70 & 0.80 & 0.20 & 6.80 & 0.81 & $\mathrm{~N} / \mathrm{NW}$ \\
\hline 7 April 2003 & 08:00 & 2 & 9.00 & 1.12 & 1.23 & 5.30 & 1.20 & 1.48 & 4.30 & 0.89 & N/NW \\
\hline 8 April 2003 & 09:00 & 1 & 6.20 & 1.16 & 0.85 & 3.90 & 1.90 & 1.62 & 4.60 & 0.80 & \\
\hline mean & & & 4.27 & 1.19 & 0.58 & 3.04 & 1.86 & 1.24 & 5.88 & 0.65 & \\
\hline median & & & 3.30 & 1.00 & 0.45 & 2.60 & 1.70 & 0.80 & 4.80 & 0.69 & \\
\hline
\end{tabular}

Table 1. Continued.

\begin{tabular}{|c|c|c|c|c|c|c|c|c|c|c|c|}
\hline Date & Starting time & class & GR 1 & $\mathrm{~J} 3$ & Cvap & $\mathrm{H}_{2} \mathrm{SO}_{4}$ & CS mean & Q & Perc. $\mathrm{H}_{2} \mathrm{SO}_{4}$ & $\mathrm{r}$ & Direction \\
\hline & & & $\left(\mathrm{nm} \mathrm{h}^{-1}\right)$ & $\left(\mathrm{cm}^{-3} \mathrm{~s}^{-1}\right)$ & $\left(\mathrm{e} 8 \mathrm{~cm}^{-3}\right)$ & $\left(\mathrm{e} 6 \mathrm{~cm}^{-3}\right)$ & $\left(\mathrm{e}-3 \mathrm{~s}^{-1}\right)$ & $\left(\mathrm{e} 5 \mathrm{~cm}^{-3} \mathrm{~s}^{-1}\right)$ & $\%$ & & \\
\hline \multicolumn{12}{|l|}{ Heidelberg } \\
\hline 15 March 2004 & $12: 00$ & 3 & 22.90 & 3.82 & 3.14 & 2.60 & 5.14 & 16.14 & 0.80 & 0.04 & SW \\
\hline 16 March 2004 & $12: 00$ & 1 & 5.70 & 1.30 & 0.78 & 6.30 & 7.14 & 5.57 & 8.10 & 0.31 & SE \\
\hline 18 March 2004 & $12: 00$ & 2 & 8.10 & 5.95 & 1.11 & 4.40 & 11.27 & 12.51 & 4.00 & 0.60 & SW \\
\hline 28 March 2004 & $14: 00$ & 3 & 6.70 & 1.42 & 0.92 & 4.20 & 9.68 & 8.91 & 4.60 & 0.79 & $\mathrm{NE}$ \\
\hline 30 March 2004 & 14:00 & 1 & 13.39 & 3.33 & 1.84 & 2.20 & 4.28 & 7.88 & 1.20 & 0.35 & NE \\
\hline 2 April 2004 & $12: 00$ & 3 & 3.30 & 4.63 & 0.45 & 3.20 & 11.63 & 5.23 & 7.10 & 0.31 & \\
\hline 3 April 2004 & $12: 00$ & 3 & 5.70 & 2.50 & 0.78 & 4.20 & 4.14 & 3.23 & 5.40 & 0.69 & \\
\hline mean & & & 8.99 & 2.67 & 1.23 & 3.46 & 6.09 & 6.97 & 4.31 & 0.53 & \\
\hline
\end{tabular}

In detail GR1 ranges from 1.6 to $12.2 \mathrm{~nm} \mathrm{~h}^{-1}$ in Hyytiälä and from 2.1 to $22.9 \mathrm{~nm} \mathrm{~h}^{-1}$ in Heidelberg with mean values of 4.27 and $8.99 \mathrm{~nm} \mathrm{~h}^{-1}$, respectively. Furthermore the growth rate in Heidelberg showed a stronger variability. From the timeshift calculations we obtained on each day a smaller growth rate for the Hyytiälä data with a mean value of $1.11 \mathrm{~nm} \mathrm{~h}^{-1}$ (Table 2). This is consistent with the result by Kulmala (2004a), who found that the growth is always smaller for the first nanometers of growth than for later growth. For Heidelberg this relation could not be observed so clearly and GR2 (mean $7.67 \mathrm{~nm} \mathrm{~h}^{-1}$ ) was sometimes higher than GR1 (mean of $8.99 \mathrm{~nm} \mathrm{~h}^{-1}$ ). Figures 8 and 9 show both 

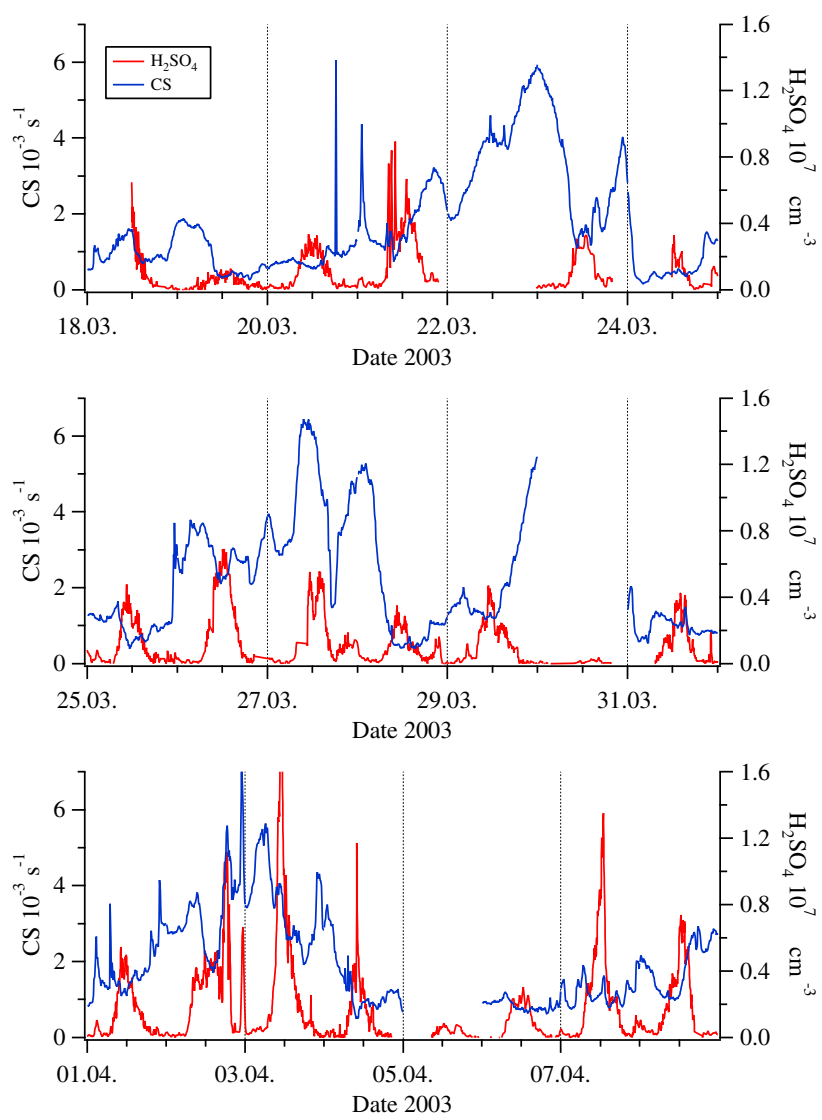

Fig. 4. Hyytiälä: Condensation sink (CS) and sulphuric acid $\left(\mathrm{H}_{2} \mathrm{SO}_{4}\right)$ versus time as an overview of the measured data.

growth rates in comparison. Possible reasons for the nearly equal growth rates GR1 and GR2 in Heidelberg could be, that the condensable vapors, here especially the ones with very low saturation vapor pressures, are probably different in regions influenced mainly by anthropogenic pollution sources compared to regions with mainly natural sources. So it might be that those organic compounds of urban origin condense easier on small one nanometer aerosol particles than the natural ones and that consequently those different gases cause different growth rates in the beginning (GR2). A second reason could be that in Heidelberg local point sources with high amounts of small particles increase the aerosol concentration. In these cases the used timeshift analysis would be inadequate and would overestimate the growth rates GR2.

The formation rates $\mathbf{J} 3$ of particles above $3 \mathrm{~nm}$ in diameter were quite similar in Hyytiälä and Heidelberg with mean values of 1.2 and $2.7 \mathrm{~cm}^{-3} \mathrm{~s}^{-1}$ and they were usually highest on class 1 event days. This result that the highest formation rates in Hyytiälä are visible on clear event days is in agreement with results published by Boy et al. (2003). With a low background particle concentration a high amount of condensable vapors is available for new particle formation. Importantly, this has to be seen in the light of the mean pre-
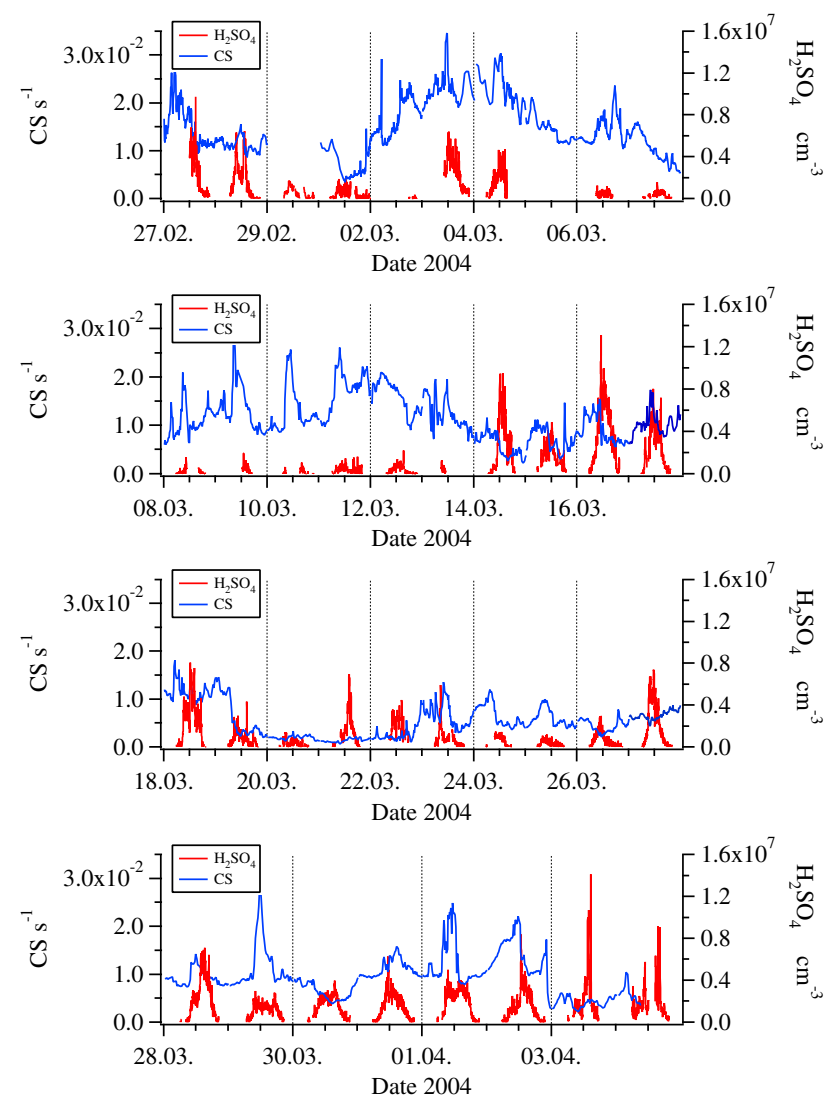

Fig. 5. Heidelberg: Condensation sink (CS) and sulphuric acid $\left(\mathrm{H}_{2} \mathrm{SO}_{4}\right)$ versus time.

existent particle concentration of each day separately. The CS was significantly lower before events than the mean CS of the corresponding day, but the day mean could be finally high, also partly caused by the new particle formation.

From the growth rates a condensable vapor concentration $C_{\text {vap }}$ was determined according to Sect. 2.3.4. Afterwards $C_{\text {vap }}$ was compared to the measured sulphuric acid concentration in order to quantify the contribution of sulphuric acid to the formation and growth rates. In case of GR1, we used the mean value of the sulphuric acid concentration during a time interval beginning with the starting time of the formation event and ending in the evening. In case of GR2, a different $\mathrm{H}_{2} \mathrm{SO}_{4}$-concentration was used because the timeshift analysis is just applied on the first rise of the $\mathrm{H}_{2} \mathrm{SO}_{4}$-curve, as explained above. Consequently, the mean sulphuric acid concentration during the timeshift interval was used.

Both $C_{v a p}$ and the percentage of sulphuric acid to the growth rates were determined for GR1 and GR2. The results can be seen in Tables 1 and 2. The percentage contribution of sulphuric acid to the particle growth in Hyytiälä was higher for GR2 (mean 17.6\%) than for GR1 (mean 5.9\%). So it seems that in Hyytiälä sulphuric acid plays a bigger role in formation and the first nanometers of growth (diameter 
Table 2. For Hyytiälä and Heidelberg, respectively, basing on the timeshift analysis: Growth Rate 2 (GR2), condensable vapor concentration $\left(C_{\text {vap }}\right)$, mean sulphuric acid concentration during timeshift interval $\left(\mathrm{H}_{2} \mathrm{SO}_{4}\right)$, mean condensation sink $(\mathrm{CS}$ mean), source rate $(Q)$, percentage of $\mathrm{H}_{2} \mathrm{SO}_{4}$ of the condensable vapor.

\begin{tabular}{|c|c|c|c|c|c|c|}
\hline Date & GR 2 & $C_{v a p}$ & $\mathrm{H}_{2} \mathrm{SO}_{4}$ & CS mean & Q & Perc. $\mathrm{H}_{2} \mathrm{SO}_{4}$ \\
\hline & $\left(\mathrm{nm} \mathrm{h}^{-1}\right)$ & $\left(\mathrm{e} 8 \mathrm{~cm}^{-3}\right)$ & $\left(\mathrm{e} 6 \mathrm{~cm}^{-3}\right)$ & $\left(\mathrm{e}-3 \mathrm{~s}^{-1}\right)$ & $\left(\mathrm{e} 5 \mathrm{~cm}^{-3} \mathrm{~s}^{-1}\right)$ & $\%$ \\
\hline \multicolumn{7}{|l|}{ Hyytiälä } \\
\hline 19 March 2003 & 0.76 & 0.10 & 0.63 & 0.90 & 0.09 & 6.05 \\
\hline 20 March 2003 & 0.83 & 0.11 & 1.91 & 0.80 & 0.09 & 16.80 \\
\hline 21 March 2003 & 1.04 & 0.14 & 3.41 & 1.90 & 0.27 & 23.93 \\
\hline 23 March 2003 & 0.69 & 0.09 & 1.29 & 3.00 & 0.28 & 13.65 \\
\hline 25 March 2003 & 2.78 & 0.38 & 1.79 & 1.10 & 0.42 & 4.70 \\
\hline 26 March 2003 & 0.93 & 0.13 & 3.62 & 2.90 & 0.37 & 28.41 \\
\hline 28 March 2003 & 0.93 & 0.13 & 1.65 & 1.70 & 0.22 & 12.95 \\
\hline 29 March 2003 & 0.93 & 0.13 & 2.44 & 2.30 & 0.29 & 19.15 \\
\hline 31 March 2003 & 0.55 & 0.08 & 1.40 & 1.00 & 0.08 & 18.58 \\
\hline 1 April 2003 & 1.04 & 0.14 & 1.76 & 1.80 & 0.26 & 12.35 \\
\hline 2 April 2003 & 0.49 & 0.07 & 2.86 & 3.30 & 0.22 & 42.60 \\
\hline 3 April 2003 & 2.78 & 0.38 & 6.64 & 3.60 & 1.37 & 17.43 \\
\hline 4 April 2003 & 0.83 & 0.11 & 2.65 & 1.40 & 0.16 & 23.30 \\
\hline 6 April 2003 & 0.76 & 0.10 & 1.10 & 0.80 & 0.08 & 10.56 \\
\hline 7 April 2003 & 1.67 & 0.23 & 2.21 & 1.20 & 0.27 & 9.66 \\
\hline 8 April 2003 & 0.76 & 0.10 & 2.25 & 1.90 & 0.20 & 21.61 \\
\hline mean & 1.11 & 0.15 & 2.35 & 1.85 & 0.29 & 17.61 \\
\hline median & 0.88 & 0.12 & 2.06 & 1.75 & 0.24 & 17.12 \\
\hline
\end{tabular}

Table 2. Continued.

\begin{tabular}{|c|c|c|c|c|c|c|}
\hline Date & GR 2 & $C_{\text {vap }}$ & $\mathrm{H}_{2} \mathrm{SO}_{4}$ & CS mean & $Q$ & Perc. $\mathrm{H}_{2} \mathrm{SO}_{4}$ \\
\hline & $\left(\mathrm{nm} \mathrm{h}^{-1}\right)$ & $\left(\mathrm{e} 8 \mathrm{~cm}^{-3}\right)$ & $\left(\mathrm{e} 6 \mathrm{~cm}^{-3}\right)$ & $\left(e-3 s^{-1}\right)$ & $\left(\mathrm{e} 5 \mathrm{~cm}^{-3} \mathrm{~s}^{-1}\right)$ & $\%$ \\
\hline \multicolumn{7}{|l|}{ Heidelberg } \\
\hline 14 March 2004 & 2.67 & 0.37 & 3.88 & 4.08 & 1.49 & 10.61 \\
\hline 15 March 2004 & 4.00 & 0.55 & 1.18 & 5.14 & 2.82 & 2.15 \\
\hline 16 March 2004 & 1.33 & 0.18 & 4.78 & 7.14 & 1.30 & 26.23 \\
\hline 18 March 2004 & 8.00 & 1.10 & 4.88 & 11.27 & 12.35 & 4.45 \\
\hline 21 March 2004 & 11.76 & 1.61 & 1.59 & 1.64 & 2.64 & 0.99 \\
\hline 22 March 2004 & 4.00 & 0.55 & 2.08 & 1.88 & 1.03 & 3.80 \\
\hline 28 March 2004 & 4.76 & 0.65 & 4.47 & 9.68 & 6.31 & 6.85 \\
\hline 30 March 2004 & 11.76 & 1.61 & 2.27 & 4.28 & 6.90 & 1.41 \\
\hline 2 April 2004 & 16.67 & 2.28 & 3.43 & 11.63 & 26.56 & 1.50 \\
\hline 3 April 2004 & 11.76 & 1.61 & 7.09 & 4.14 & 6.67 & 4.40 \\
\hline mean & 7.67 & 1.05 & 3.57 & 6.09 & 6.81 & 6.24 \\
\hline median & 6.38 & 0.87 & 3.66 & 4.71 & 4.56 & 4.10 \\
\hline
\end{tabular}

smaller than $3 \mathrm{~nm}$ ) than in later growth. In Heidelberg this behavior could not be seen so clearly, but both percentages were about the same (mean $4.3 \%$ for GR1 and $6.2 \%$ for GR2). Here again high concentrations of anthropogenic con- densable trace gases could be responsible. They might partly substitute sulphuric acid in its important role specifically in aerosol formation and initial growth. Furthermore the percentage contribution calculated from GR1 was almost the 

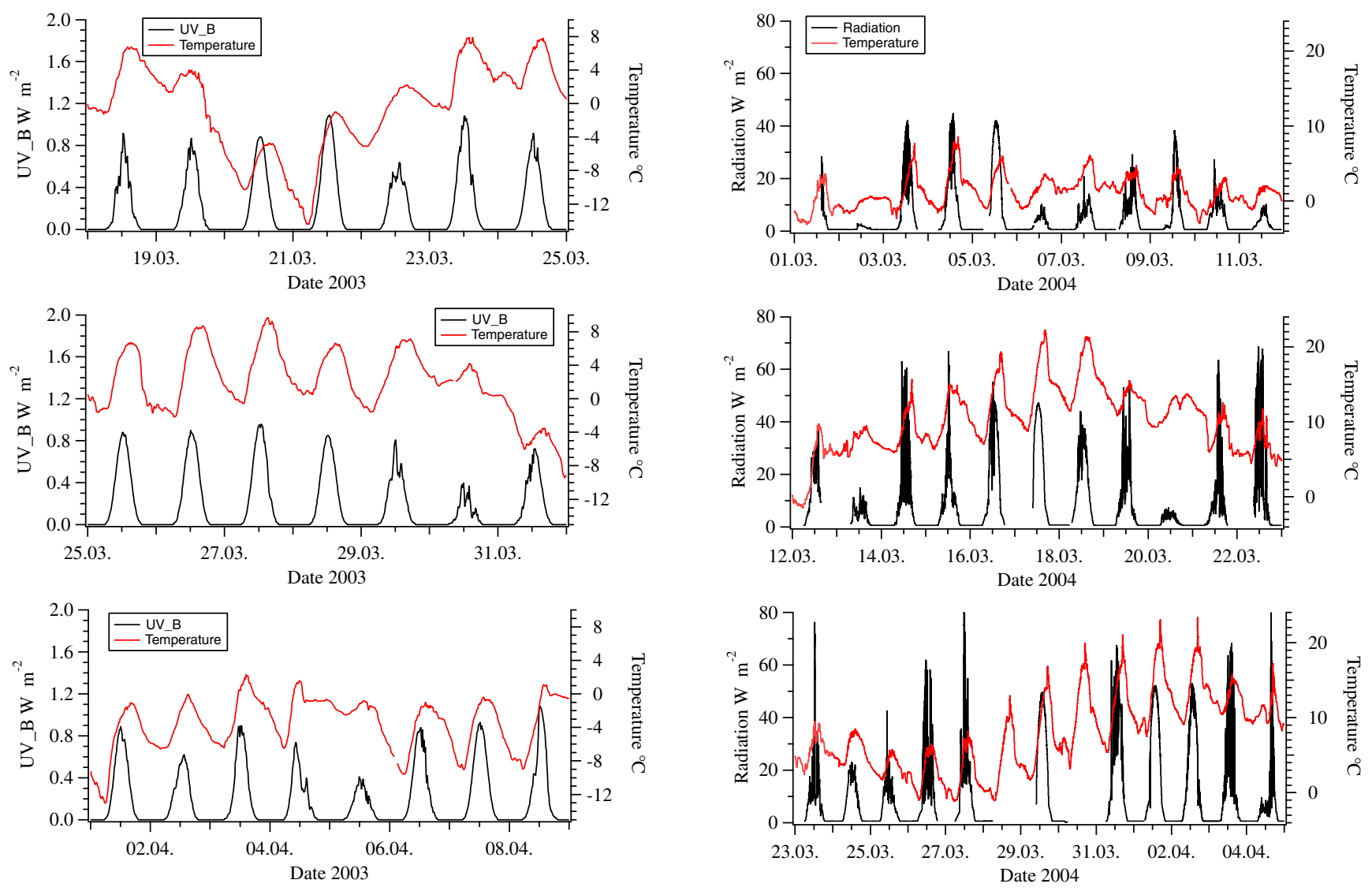

Fig. 6. Hyytiälä: UV-B radiation and temperature versus time as overview on which days the weather conditions for production of sulphuric acid were favorable.

same at both measurement sites (5.9 and 4.3\%), which means that sulphuric acid seems to contribute to particle growth in about the same percentage, independent from the two station locations. At Heidelberg the percentage contribution calculated from GR2 was smaller than at Hyytiälä.

Subsequently the source rate $Q$ was calculated from the condensable vapor concentration and the mean condensation sink according to Eq. (5). Q depends only on these two parameters and consequently it was higher in Heidelberg than in Hyytiälä. Again the more polluted air in Heidelberg should be the reason for the higher source rates of sulphuric acid. Interestingly, the increased source and sink terms of $\mathrm{H}_{2} \mathrm{SO}_{4}$ in Heidelberg air seem to balance so that concentrations comparable to Hyytiälä are observed.

The next point analyzed was the correlation between sulphuric acid and the smallest detectable particles between 3 and $6 \mathrm{~nm}(\mathrm{~N} 3)$. As mentioned above we would expect a similar shape of the two curves $\mathrm{H}_{2} \mathrm{SO}_{4}$ versus time and $\mathrm{N} 3$ versus time with a certain time lag due to the fact that sulphuric acid is the most important factor involved in new particle formation. More precisely, if sulphuric acid was the only substance responsible for new particle formation, both curves should

Fig. 7. Heidelberg: Total solar radiation and temperature versus time.

have exactly the same shape. Consequently, the correlation between those two curves indicates the relation between sulphuric acid and newly formed aerosols. Figure 10 gives one example of these analyses for Hyytiälä and Heidelberg, respectively. In these graphs $\mathrm{N} 3$ is plotted versus $\mathrm{H}_{2} \mathrm{SO}_{4}$. On many days a direct correlation was found as in the Heidelberg example, on many other days the correlation required a certain timeshift as in the Hyytiälä example (this timeshift is the same as used in the timeshift analyses of the growth rates). There were also days where no correlation was found, especially in Heidelberg. In Table 1 the corresponding linear correlation coefficients can be found.

Figure 11 shows the particle number concentration between 3 and $6 \mathrm{~nm}$ plotted versus the condensation sink at both measurement sites and the sulphuric acid concentration as color code. In Hyytiälä the concentration of small particles is highest at low CS values and decreases steeply for high CS values. Or with high CS values at least high concentrations of sulphuric acid are needed in order to get a significant amount of new small particles. Yet at Heidelberg high $\mathrm{N} 3$ values occur even with high CS and low sulphuric acid values. This could be explained once more by local and temporarily high emission of particles and/or high amounts of 


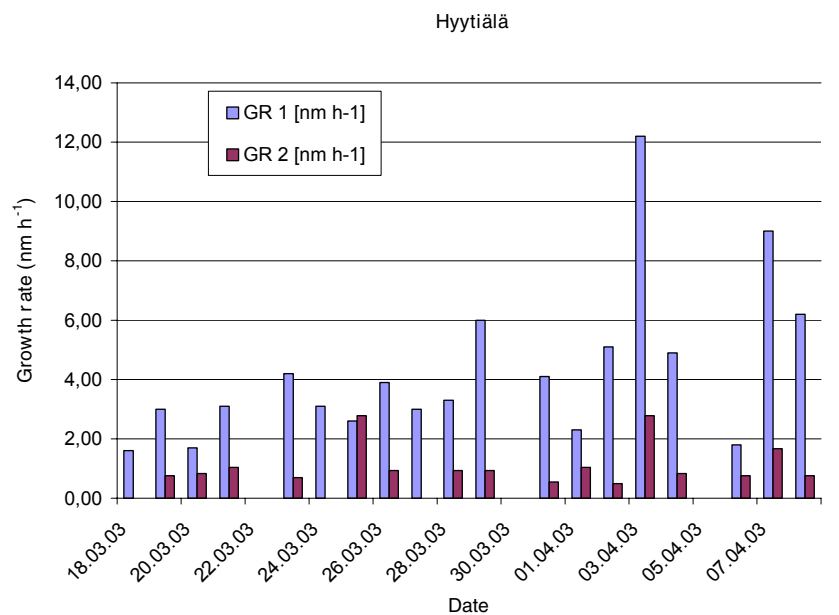

Fig. 8. Hyytiälä: Comparison Growth Rate 1 (GR1), growth starting at $3 \mathrm{~nm}$, and Growth Rate 2 (GR2), initial growth from $1 \mathrm{~nm}$ to $3 \mathrm{~nm}$. The initial growth was usually slower than later growth (GR2<GR1).

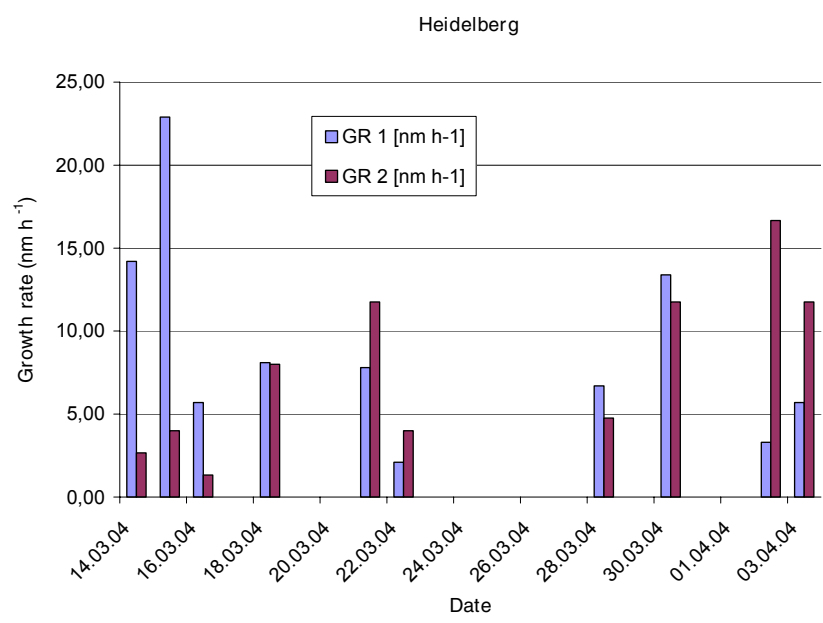

Fig. 9. Heidelberg: Comparison Growth Rate 1 (GR1), growth starting at $3 \mathrm{~nm}$, and Growth Rate 2 (GR2), initial growth from $1 \mathrm{~nm}$ to $3 \mathrm{~nm}$.

condensable vapors by anthropogenic sources. During these periods sulphuric acid may contribute only partly to the concentration of the N3 aerosols, which would explain the bad correlations.

Finally air mass trajectories on event days were investigated. The air mass direction on event days is also added to Table 1. For Hyytiälä data it has been already found out that on event days with less polluted air, originating from polar or Atlantic regions, CS is 2.64 times, sulphuric acid 1.46 times and growth rates are 1.45 times lower than on days with polluted air masses originating over industrial areas (Boy et al., 2005). Moreover events occur more likely on days with clean air masses.
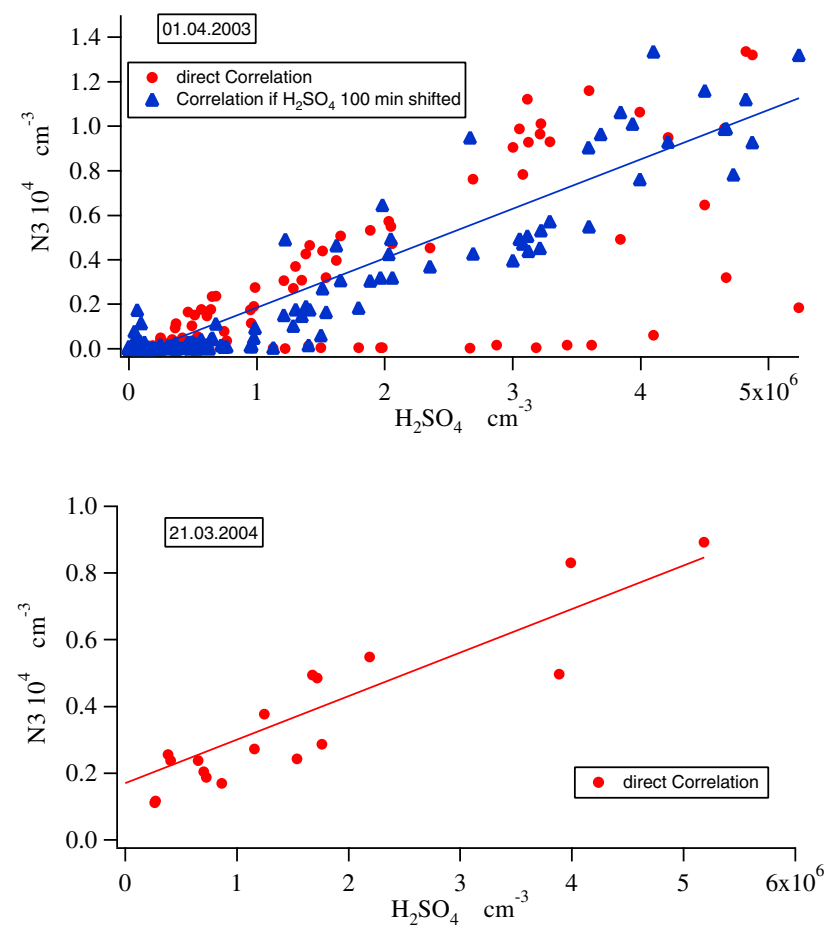

Fig. 10. Examples for good correlations between sulphuric acid concentration $\left(\mathrm{H}_{2} \mathrm{SO}_{4}\right)$ and particle number concentration between 3 and $6 \mathrm{~nm}(\mathrm{~N} 3)$. First panel Hyytiälä: good correlation after a timeshift of $100 \mathrm{~min}$, second panel Heidelberg.

Table 3. Comparison of Condensation Sink, Sulphuric acid concentration and Growth Rate on polluted days in Heidelberg and Hyytiälä.

\begin{tabular}{lcc}
\hline & Hyytiälä & Heidelberg \\
\hline $\mathrm{CS}\left(\mathrm{e}-3 \mathrm{~s} \mathrm{~s}^{-1}\right)$ & 2.90 & 6.09 \\
$\mathrm{H}_{2} \mathrm{SO}_{4}\left(\mathrm{e} 6 \mathrm{~cm}^{-3}\right)$ & 3.31 & 3.46 \\
$\mathrm{GR}\left(\mathrm{nm} \mathrm{h}^{-1}\right)$ & 3.20 & 8.99 \\
\hline
\end{tabular}

For Heidelberg it was practically impossible to get days with clear, non polluted air because of its central European location. Nevertheless, events were preferably found on days with air masses advected from South-West or West, originating over the Mediterranean Sea or the Atlantic. No events occurred on days with air masses originating over the North Sea and Baltic Sea, which approach Heidelberg from the North and North-West. Those northern air masses passed the industrial areas around Mannheim/Ludwigshafen and are probably more polluted than the ones from South-West, which corresponds to the Hyytiälä result that events preferably occur on less polluted days.

Table 3 compiles mean values of condensation sink, sulphuric acid concentration and growth rate on polluted days 

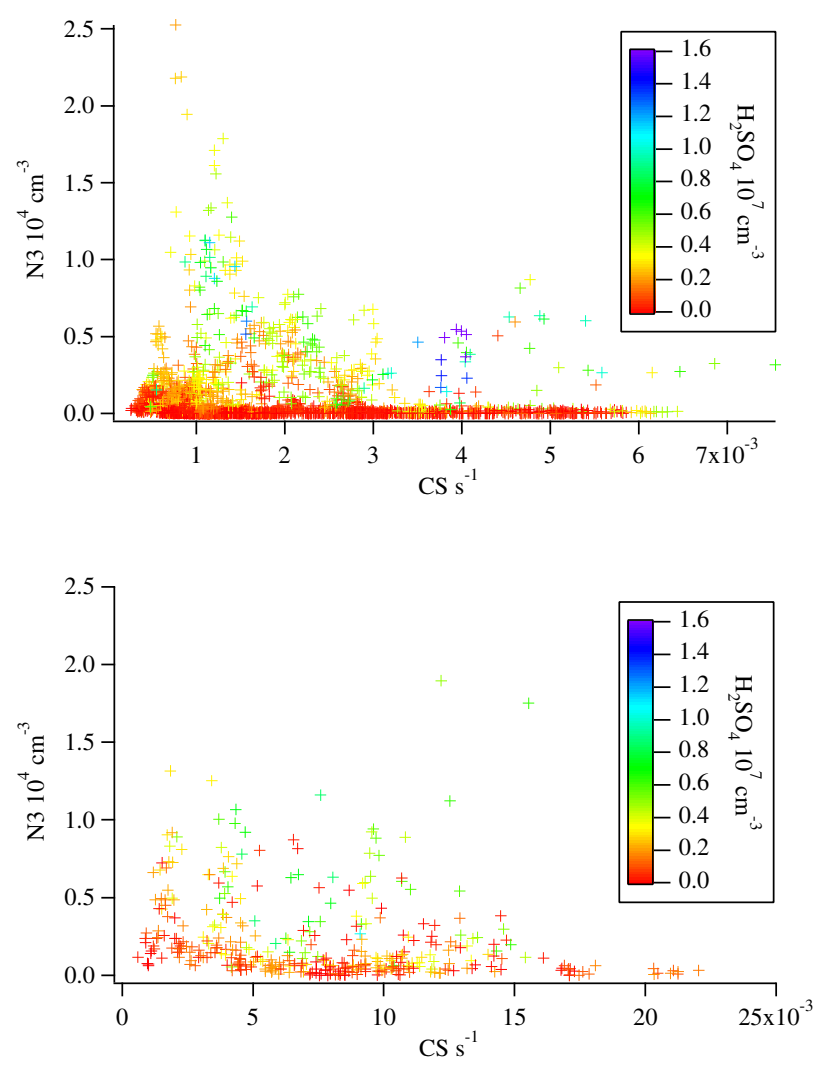

Fig. 11. Particle number concentration between 3 and $6 \mathrm{~nm}(\mathrm{~N} 3)$ versus condensation sink (CS), sulphuric acid concentration as color code. First panel Hyytiälä: It can be seen that N3 is high either if $\mathrm{CS}$ is low or with higher $\mathrm{CS}$ the $\mathrm{H}_{2} \mathrm{SO}_{4}$ concentration needs to be high. Second panel Heidelberg: High N3 values can be found even with high $\mathrm{CS}$ and low $\mathrm{H}_{2} \mathrm{SO}_{4}$.

in Finland and Germany. The mean values for Hyytiälä are taken from Boy et al. (2005). CS and GR1 are 2 to 3 times higher in Heidelberg compared to Hyytiälä; a fact which was pointed out already earlier and reflects the much higher anthropogenic influence in Central Europe compared to Northern Europe. Since the sulphuric acid concentrations are quite similar at both sites we come a third time to the conclusion that other vapors than $\mathrm{H}_{2} \mathrm{SO}_{4}$ seem to play a very important role in new particle formation.

\section{Conclusions and perspectives}

In this work measurements of atmospheric gaseous sulphuric acid and aerosol particles carried out in Hyytiälä, Finland, and Heidelberg, Germany, were compared.

First of all higher measured condensation sink and growth rate values were found in Heidelberg compared to Hyytiälä which reflects the higher degree of pollution in Germany. Nevertheless, the measured sulphuric acid concentrations were about the same at both measurement sites. This also concerns the percentage contribution of sulphuric acid to new particle formation and growth at both sites (5.9 and 4.3\%, respectively) in case of GR1 (a total growth rate for the whole event), which suggests that sulphuric acid contributes to particle growth in about the same percentage at both station locations.

GR2, calculated with the timeshift analysis, allowed to determine a growth rate specifically for the initial growth from $1 \mathrm{~nm}$ up to a size of $3 \mathrm{~nm}$. The values were in average smaller than GR1 in Hyytiälä, which was already earlier pointed out by Kulmala (Kulmala et al., 2004a), so the growth seems to be initially slower compared to later. Moreover, the percentage contribution of sulphuric acid to particle growth was for Hyytiälä higher in the beginning (17.6\% for GR2 and 5.9\% for GR1), which means that sulphuric acid seems to play a bigger role in the first two nanometers of growth from $1 \mathrm{~nm}$ up to $3 \mathrm{~nm}$ in diameter than in later growth. In Heidelberg both growth rates and the percentages calculated from them were about the same. The stronger initial growth and the lower sulphuric acid contribution in Heidelberg compared to Hyytiälä may both be explained by the influence of other condensable trace gases, here especially compounds with low saturation vapor pressure and anthropogenic origin, that might substitute sulphuric acid in its important role in new particle formation and especially initial growth or simply by the fact that the timeshift analysis gives inadequate results if the correlation between $\mathrm{H}_{2} \mathrm{SO}_{4}$ and $\mathrm{N} 3$ is not very pronounced. A correlation analysis between sulphuric acid and the particles between 3 and $6 \mathrm{~nm}$ gave exactly this result, i.e. the correlation in Hyytiälä was quite clear in contrast to Heidelberg. Generally the results in Heidelberg were less clear; most probable temporarily and locally high amounts of other condensable trace gases from anthropogenic sources mask the influence of sulphuric acid.

In future experiments it would be desirable to identify the nature of those other substances. In recent years already condensable organic trace gases (VOC) have been taken into account for this role, but the analysis of such organics is quite difficult because of the wide range of different substances, often different substances with the same molecular mass. Therefore further analyses are needed.

Edited by: A. Laaksonen

\section{References}

Aalto, P., Hämeri, K., Becker, E., Weber, R., Salm, J., Mäkelä, J. M., Hoell, C., O’Dowd, C. D., Karlsson, H., Hansson, H.-C., Väkevä, M., Koponen, I. K., Buzorius, G., and Kulmala, M.: Physical characterization of aerosol particles during nucleation events, Tellus, 53 B, 344-358, 2001.

Arnold, F.: Ion nucleation - a potential source for stratospheric aerosols, Nature, 299, 134-137, 1982.

Birmili, W., Stratmann, F., and Wiedensohler, A.: Design of a DMA-based size spectrometer for a large particle size range and stable operation, J. Aer. Sci., 30, 549-553, 1999. 
Birmili, W., Berresheim, H., Plass-Dülmer, C., Elste, T., Gilge, S., Wiedensohler, A., and Uhrner, U.: The Hohenpeissenberg aerosol formation experiment (HAFEX): A long-term study including size-resolved aerosol, $\mathrm{H}_{2} \mathrm{SO}_{4}, \mathrm{OH}$, and monoterpenes measurements, Atmos. Chem. Phys., 3, 361-376, 2003,

\section{SRef-ID: 1680-7324/acp/2003-3-361.}

Boy, M. and Kulmala, M.: Nucleation events in the continental boundary layer: Influence of physical and meteorological parameters, Atmos. Chem. Phys., 2, 1-16, 2002,

SRef-ID: 1680-7324/acp/2002-2-1.

Boy, M., Rannik, Ü., Lehtinen, K. E. J., Tarvainen, V., Hakola, H., and Kulmala, M.: Nucleation events in the continental PBL long term statistical analyses of aerosol relevant characteristics, J. Geophys. Res., 108 (D21), 4667-4680, 2003.

Boy, M., Kulmala, M., Ruuskanen, T. M., Pihlatie, M., Reissell, A., Aalto, P. P., Keronen, P., Hellen, H., Hakola, H., Jansson, R., Hanke, M., and Arnold, F.: Sulphuric acid closure and contribution to nucleation mode particle growth, Atmos. Chem. Phys., 5, 863-878, 2005,

SRef-ID: 1680-7324/acp/2005-5-863.

Fuchs, N. A. and Sutugin, A. G.: Highly dispersed aerosol, in: Topics in current aerosol research, edited by: Hidy, G. M. and Brock, J. R., Pergamon, New York, 1971.

Garrett, T. J., Radke, L. F., and Hobbs, P. V.: Aerosol Effects on Cloud Emissivity and Surface Longwave Heating in the Arctic, J. Atmos. Sci., 59, 769-778, 2002.

Hanke, M., Uecker, J., Reiner, T., and Arnold, F.: Atmospheric peroxy radicals: ROXMAS, a new mass-spectrometric methodology for speciated measurements of $\mathrm{HO} 2$ and Sigma $\mathrm{RO} 2$ and first results, International Journal of Mass Spectrometry, 213(23), 91-99, 2002.

Harshvardhan, Schwarz, S. E., Benkovitz, C. M., and Guo, G.: Aerosol Influence on Cloud Microphysics Examined by Satellite Measurements and Chemical Transport Modelling, J. Atmos. Sci., 59, 714-725, 2002.

Harrison, R. M., Grenfell, J. L., Savage, N., Allen, A., Clemitshaw, K. C., Penkett, S., Hewitt, C. N., and Davison, B.: Observations of new particle production in the atmosphere of a moderately polluted site in eastern England, J. Geophys. Res., D105, 17 819$17832,2000$.

Kerminen, V.-M., Pirjola, L. and Kulmala, M.: How significantly does coagulational scavenging limit atmospheric particle production, J. Geophys. Res., 106, 24 119-24 125, 2001.

Kim, C. S. and Jaques, P. A.: Respiratory dose of inhaled ultrafine particles in healthy adults, Phil. Trans. R. Soc. Lond. A., 358, 2693-2705, 2000.

Korhonen, P., Kulmala, M., Laaksonen, A., Viisanen, Y., McGraw, R., and Seinfeld, J. H.: Ternary nucleation of $\mathrm{H}_{2} \mathrm{SO}_{4}, \mathrm{NH}_{3}$ and $\mathrm{H}_{2} \mathrm{O}$ in the atmosphere, J. Geophys. Res., 104, 26349-26353, 1999.

Kulmala, M.: Nucleation as an aerosol physical problem, $\mathrm{PhD}$ thesis, University of Helsinki, 1988.

Kulmala, M., Toivonen, A., Mäkelä, J. M. and Laaksonen, A.: Analysis of the growth of nucleation mode particles observed in Boreal forest, Tellus B, 50, 449-462, 1998.
Kulmala, M., Dal Maso, M., Mäkelä, J. M., Pirjola, L., Väkevä, M., Aalto, P., Miikkulainen, P., Hämeri, K., and O'Dowd, C.: On the formation, growth and composition of nucleation mode particles, Tellus B, 53, 479-490, 2001.

Kulmala, M.: How particles nucleate and grow, Science, 307 (5647), 1000-1001, 2003.

Kulmala, M., Laakso, L., Lehtinen, K. E. J., Riipinen, I., Dal Maso, M., Anttila, T., Kerminen, V.-M., Hõrrak, U., Vana, M., and Tammet, H.: Initial Steps of Aerosol Growth, Atmos. Chem. Phys., 4, 2553-2560, 2004a,

SRef-ID: 1680-7324/acp/2004-4-2553.

Kulmala, M., Vehkamäki, H., Petäjä, T., Dal Maso, M., Lauri, A., Kerminen, V.-M., Birmili, W., and McMurry, P. H.: Formation and growth rates of ultrafine atmospheric particles: A review of observations, J. Aerosol Sci., 35, 2, 143-176, 2004 b.

Mäkelä, J. M., Dal Maso, M., Laaksonen, A., Kulmala, M., Pirjola, L., Keronen, P., and Laakso, L.: Characteristics of the aerosol particle formation events observed at a boreal forest site in southern Finland, Boreal Environment Research, 5, 299-313, 2000.

Menon, S. and Saxena, V. K.: Role of sulfates in regional cloudclimate interactions, Atmos. Res., 47-48, 299-315, 1998.

Ramanathan, V., Crutzen, P. J., Kiehl, J. T., and Rosenfeld, D.: Aerosol, climate, and the hydrological cycle, Science, 294, 2119-2124, 2001.

Reiner, T. and Arnold, F.: Laboratory flow reactor measurements of the reaction $\mathrm{SO}_{3}+\mathrm{H}_{2} \mathrm{O}+\mathrm{M} \rightarrow \mathrm{H}_{2} \mathrm{SO}_{4}+\mathrm{M}$ : Implications for gaseous $\mathrm{H}_{2} \mathrm{SO}_{4}$ and aerosol formation in the plume of a jet aircraft, Geophys. Res. Lett., 20, 2659-2662, 1993.

Reiner, T. and Arnold, F.: Laboratory investigations of gaseous sulphuric acid formation via $\mathrm{SO}_{3}+\mathrm{H}_{2} \mathrm{O}+\mathrm{M} \rightarrow \mathrm{H}_{2} \mathrm{SO}_{4}+\mathrm{M}$ : Measurements of the rate constant and product identification, J. Chem. Phys., 101, 7399-7407, 1994.

Stieb, D. M., Judek, S., and Burnett, R. T.: Meta-analysis of timeseries studies of air pollution and mortality: Effects of gases and particles and their influence of cause of death, age and season, J. Air \& Manage. Assoc., 52, 470-484, 2002.

Weber, R. J., Marti, J. J., McMurry, P. H., Eisele, F. L., Tanner, D. J., and Jefferson, A.: Measurements of new particle formation and ultrafine particle growth rates at a clean continental site, J. Geophys. Res., D102, 4375-4385, 1997.

Weber, R. J., McMurry, P. H., Mauldin, L., Tanner, D., Eisele, F., Clarke, A. D., and Kapustin, V. N.: New Particle Formation in the Remote Troposphere: A Comparison of Observation at Various Sites, Geophys. Res. Lett., 26, 307-310, 1999.

Wichmann, H.-H. and Peters, A.: Epidemiological evidence of the effects of ultrafine particle exposure, Phil. Trans. R. Soc. Lond. A., 358, 2751-2769, 2000.

Yue, G. and Chan, L.: Theory of formation of aerosols of volatile binary solutions through the ion-induced nucleation process, J. Colloid Interface Sci., 68, 501-507, 1979. 